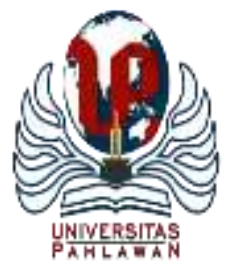

Edukatif : Jurnal Ilmu Pendidikan Volume 3 Nomor 6 Tahun 2021 Halm 3919 - 3927

EDUKATIF: JURNAL ILMU PENDIDIKAN

Research \& Learning in Education

https://edukatif.org/index.php/edukatif/index

\title{
Penerapan Sistem Prodigy Math Game sebagai Implementasi Merdeka Belajar dalam Meningkatkan Minat Belajar Siswa Menengah Atas
}

\author{
Yelsi Enny $A^{1 凶}$, Hotmaulina Sihotang ${ }^{\otimes 2}$ \\ Program Sarjana Prodi Pendidikan Matematika, Universitas Kristen Indonesia, Indonesia ${ }^{1,2}$ \\ E-mail : yelsienny06@ gmail.com ${ }^{1}$, hotmaulina.sihotang@ uki.ac.id ${ }^{2}$
}

\begin{abstract}
Abstrak
Pembelajaran matematika merupakan salah satu pelajaran yang penting dikarenakan dari tingkat Sekolah Dasar (SD) hingga Sekolah Menengah Atas (SMA) dipelajari namun ketika pembelajaran daring siswa kurang aktif dan kesulitan menyelesaikan masalah. Tujuan penelitian ini adalah membatu siswa aktif belajar dan memecahkan masalah dengan menerapkan system prodidy math. Metode penelitian ini dengan studi literatur yakni mengkaji regulasi, buku, dan jurnal. Hasil penelitian menunjukkan penerapan prodigy math game pada siswa sebagai media tambahan disaat pembelajaran daring dapat mengatasi permasalahan siswa yang sulit untuk memahami pembelajaran matematika dan menumbuhkan keaktifan serta minat siswa untuk belajar matematika disaat kelas online berlangsung. Penerapan system prodigy math game dapat dilihat dari hasil analisis secara kualitatif dengan pendekatan induktif yang mengacu pada permasalahan yang ada dalam kehidupan sehari-hari mampu membuat siswa menjadi aktif dan berpikir kreatif selama pembelajaran daring. System prodigy math dapat meningkatkan nilai minat dan semangat belajar siswa saat pembelajaran daring berlangsung dan sebagai implementasi dari merdeka belajar.
\end{abstract}

Kata kunci: System prodigy math game; merdeka belajar; minat belajar.

\begin{abstract}
Learning mathematics is one of the important lessons because from elementary school to senior high school but when online learning students are less active and have difficulty solving problems. The purpose of this research is to help students actively learn and solve problems by applying the prodigy math system. This research method uses literature studies, namely reviewing regulations, books, and journals. The results show that the application of prodigy math games to students as an additional medium when online learning can overcome students' problems that are difficult to understand mathematics learning and foster student activity and interest in learning mathematics when online classes take place. The application of the prodigy math game system can be seen from the results of a qualitative analysis with an inductive approach that refers to problems that exist in everyday life that are able to make students active and think creatively during online learning. The prodigy math system can increase the value of students' interest and enthusiasm for learning when online learning takes place and as an implementation of independent learning.
\end{abstract}

Keyword: Mathematical mathematical gaming system; Free study; Study hard.

Copyright (c) 2021 Yelsi Enny A, Hotmaulina Sihotang

$\triangle$ Corresponding author

Email : hotmaulina.sihotang@uki.ac.id

DOI : https://doi.org/10.31004/edukatif.v3i6.1230

ISSN 2656-8063 (Media Cetak)

ISSN 2656-8071 (Media Online) 
3920 Penerapan Sistem Prodigy Math Game sebagai Implementasi Merdeka Belajar dalam Meningkatkan Minat Belajar Siswa Menengah Atas - Yelsi Enny A, Hotmaulina Sihotang

DOI: https://doi.org/10.31004/edukatif.v3i6.1230

\section{PENDAHULUAN}

Pembelajaran matematika merupakan pelajaran yang penting dan sudah tidak asing lagi bagi setiap orang yang pernah merasakan duduk di bangku sekolah, baik dari Sekolah Dasar (SD) hingga Sekolah Menengah Atas (SMA). Tentu setiap orang memiliki kesan tersendiri ketika mempelajari suatu pembelajaran entah itu pembelajaran yang disukai atau pembelajaran yang tidak disukai sama sekali, begitupula dengan mempelajari matematika. Sebagain besar siswa di Indonesia berpendapat dan sudah tertanam dalam pola pikir mereka bahwa pelajaran matematika itu merupakan suatu pelajaran yang sulit untuk dipahami, dan belum lagi kondisi kelas yang sangat monoton dikarenakan guru yang kurang kreatif dan kurang aktif untuk membuat suatu pembelajaran menjadi menarik, bahkan yang menjadi miris adalah ketakutan siswa dalam mempelajari matematika adalah dikarenakan gurunya galak. Pada dasarnya belajar matematika merupakan belajar konsep, sedangkan konsep-konsep dasar matematika merupakan kesatuan holistik dan komprehensif yang saling berkaitan dan terhubung satu sama lain. Progresivisme adalah salah satu aliran filsafat pendidikan modern yang menginginkan adanya perubahan mendasar terhadap pelaksanaan pendidikan ke arah yang lebih baik, berkualitas dan memberikan kemanfaatan yang nyata bagi peserta didik (Mustaghfiroh, 2020). Konsep pendidikan mengacu pada filsafat progresivisme yang sejalan dengan pertumbuhan manusia. Manusia akan terus mengikuti perkembangan secara dinamis sepanjang manusia itu sendiri tumbuh dan berkembang di zamannya, maka pendidikanpun harus menyesuaikan akan hal tersebut. Hal ini sejalan dengan konsep live long education (pendidikan seumur hidup) yang menekankan pendidikan harus menyesuaikan dengan kondisi zaman (Aiman Faiz1, 2020).

Terbukti melalui Program For International Student Assessment hasil tes PISA 2015-2018 menunjukan bahwa Indonesia berada pada urutan 75 dari 80 negara. Bahkan terjadi penurunan 7 poin jika dibandingkan dari hasil tes PISA pada tahun 2015. Mengingat, matematika mengajarkan seseorang untuk dapat bisa berpikir logis, kritis, analisis, sistematis, dan kreatif. Maka banyak upaya yang dilakukan dari berbagai pihak untuk keberhasilan dan meningkatkan kualitas pendidikan matematika, secara kuhsus di negara Indonesia yang dinilai sangat kurang dalam pelajaran matematika. Untuk itu dalam proses belajar mengajar yang terpenting sebenarnya adalah bagaimana seorang guru dapat mengajarkan konsep matematika dengan baik dan siswa dapat memahami dan mengikuti pembelajaran di kelas dengan menyenangkan. peran pendidikan adalah meneruskan kebudayaan dan mempertahankan tatanan masyarakat. Melalui pendidikan, generasi muda diajarkan tentang berbagai peran agar dapat berfungsi efektif dalam kehidupan bermasyarakat (Samho, 2014).

Dalam rangka meningkatkan prestasi belajar siswa selama pembelajaran daring didapati bahwa, kurangnya minat siswa dalam belajar dan ketidakseriusan siswa dalam mengikuti pembelajaran, menjadi hal yang cukup rumit memastikan apakah siswa tersebut dapat paham dan mengerti apa yang disampikan ketika kelas online berlangsung, dikarenakan keterbatasan jarak dan sulitnya melihat dan memastikan bahwa siswa tersebut benar-benar mengikuti setiap pembelajaran selayaknya pembelajaran di saat offline berlangsung. Untuk itu diperlukan suatu cara yang kreatif dalam meningkatkan nilai minat belajar siswa, dari suatu system aplikasi game matematika yang berupa System prodigy math game.

System prodigy math game dirilis pada tangal 29 Mei 2018. System ini memiliki proses untuk mengevaluasi dari seluruh potensi pembelajaran yang ada didalam pembelajaran matematika dari tingkat Sekolah Dasar (SD) hingga Sekolah Menengah Atas. System prodigy math game menggunakan cara mengidentifikasi dan pemecahan masalah dalam kehidupan sehari-hari yang dimana ternyata sebenarnya sangat sering digunakan dalam kehidupan sehari-hari (Lyons, 2020). Masalahnya adalah kita sering menggunakannya secara bersamaan. Tanpa kita sadari dan sebenarnya harus dimengerti dengan baik cara pengunannya yang tepat. Agar siswa dapat mengoptimalkan segala hal dengan baik dan tepat dalam memahami konsep pembelajaran metematika yang merupakan kesatuan holistic dan komperehensif yang dimana saling berkitan dan saling melengkapi satu samalain (Krisbiantoro1 \& Haryono2, 2017). 
Cara penggunaan yang tidak dimengerti menyebabkan terjadinya suatu masalah yang dimana ketidakseimbangan dalam pengambilan suatu keputusan. Hal ini memengaruhi segala hal yang terjadi dalam kehidupan setiap individu dan pastinya siswapun termasuk didalamnya. Kita perlu mengetahui bahwa kunci untuk dapat bisa berpikir kreatif adalah menggunakan kedua pemikiran homogen dan divergent thinking secara bergantian. Sehingga, ketika kita sedang menggunakan divergent thinking, cobalah untuk mengali dan menghasilkan ide sebanyak-banyaknya. Kemudian, jangan pernah sekalipun menghakimi dan memberi komentar yang berlebihan kepada perserta didik atau orang lain. Biarkan saja mereka mencoba hal-hal baru yang dimana nantinya bisa memicu teman-teman yang lain menghasilkan ide yang unik, dan kreatif, intinya beri siswa ruang untuk mengembangkan kemampuan dan hal yang merekai sukai dan senangi. Karena, kebebasan berpendapat memicu seseorang untuk dapat meningkatkan nilai minat belajar serta berpikir kritis siswa dan pada akhirnya siswa akan mencoba hal-hal baru perlu yang dimana gurupun seharusnya mengerti apa yang di perlukan dan tentunya harus mendukung dan mendampingi setiap siswa. Pembentukan karakter dipengaruhi oleh pengaruh lingkungan, baik lingkungan di rumah, di sekolah , di dalam masyarakat, di dalam kehidupan berbangsa (Sihotang, n.d.).

Perlu di ketahui ketika mereka melakukan convergent thinking, ide-ide yang dihasilkan oleh divergent thinking boleh diberikan masukan dan saran yang bertahap tidak bisa secara langsung dan yang paling penting tentunya tidak menyingung perasaan siswa atau orang lain. Jadi, system prodigy math game bisa dijadikan salah satu media tambahan untuk belajar matematika pada saat pembelajaran daring yang dimana setiap oarang di tuntut untuk berpikir kedepan dan menuntut setiap orang untuk terus berpikir kedepan, dan bagaimana mengubah suatu kebiasaan lama menjadi lebih baik dengan cara yang kreatif, belum lagi kita ternyata bertarung dengan kondisi yang tidak bisa diprediksi dengan pasti seperti apa yang akan terjadi kedepannya tidak ada yang tahu pasti, seperti apa yang sedang di alami saat ini yaitu pandemi Covid 19. Di tengah pandemi Covid-19 saat ini, ada banyak sekali tantangan yang harus dihadapi oleh guru, orangtua, dan murid. Guru menghadapi era baru dan situasi yang tidak mudah. Secara radikal guru harus mengubah pola pembelajaran (Hotmaulina Sihotang1*), Bernadetha Nadeak2), 2020).

Sehingga ketika belajar dimasa pandemik saat ini seharusnya siswa di berikan kebebasan untuk dapat memahami hal yang sedang dipelajari tanpa bataan dan biarkan mereka mencoba hal-hal baru yang sebelumnya belum pernah mereka coba dan kerjakan terkait soal dan aktivitas yang nantinya akan di kerjakan oleh setiap siswa yang berada didalam kelas online. Pengunaan dari System prodigy math game sebagai media tambahan dalam pembelajaran matematika yang dimana merupakan budaya baru, hal baru, dan perlu sangat dipahami bahwa ini adalah awal baru sebagai tahapan perubahan seluruh tingkah laku bagi umat manusia pada jaman ini yang relatif menetap sebagai hasil pengalaman dan interaksi dengan lingkungan. Proses penggunaan suatu system pembelajaran dari suatu media pembelajaran salah satunya adalah sistem dari aplikasi prodigy mate game, yang dimana di harapkan dapat meningkatkan semangat belajar matematika, mengingat pembelajaran matematika itu sendiri diharapkan dapat mengajarkan seseorang untuk dapat bisa berpikir logis, kritis, analisis, sistematis, dan kreatif (Sihotang, 2012). 


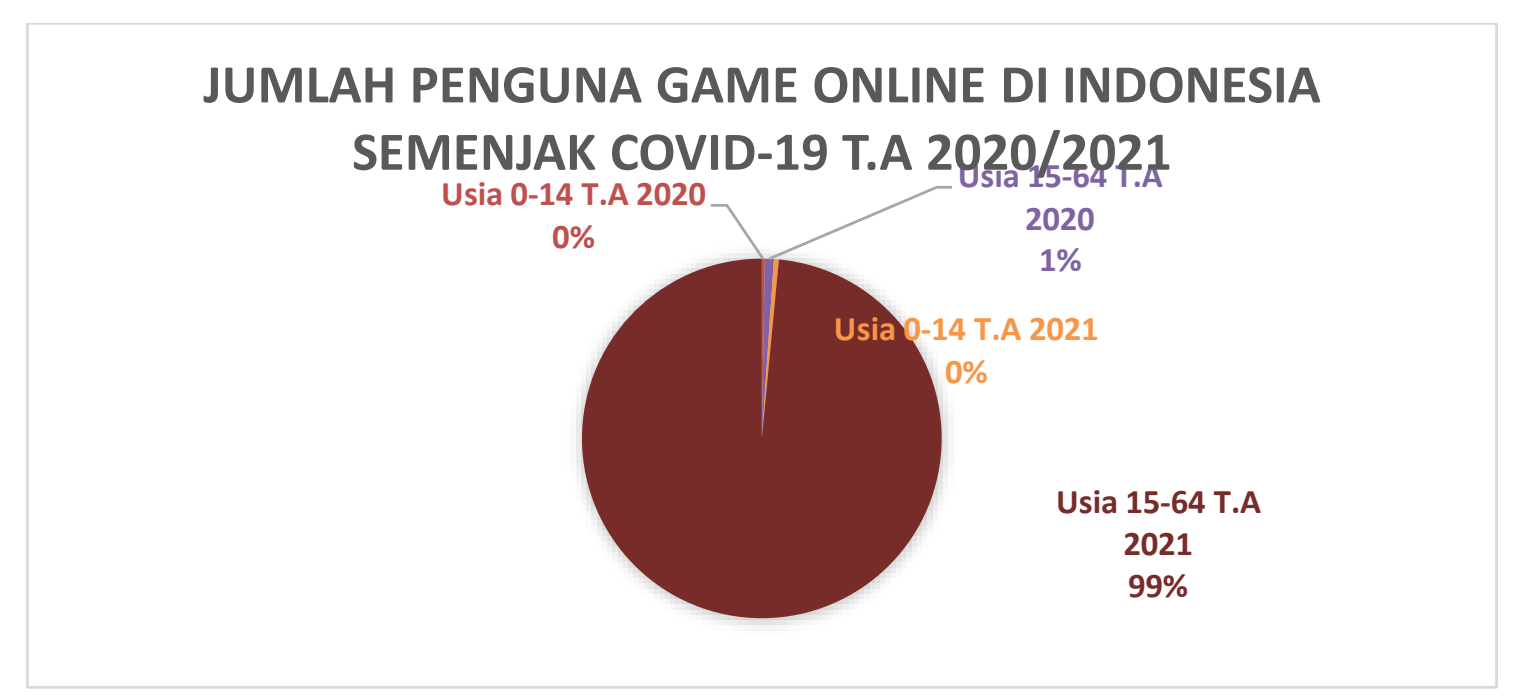

Gambar 1. Jumlah Penguna Game Online di Indonesia Semenjak Covid-19 T.A 2020/2021

Dari hasil penelitian menurut Jakarta, investor.id terdata jumlah usia produktif penduduk di Indonesia dari hasil senus penduduk 2020 menunjukan bahwa jumlah penduduk usia produktif (15-64 tahun) mencapai $70,72 \%$ dari total jumlah penduduk Indonesia yang sebesar 270,20 juta atau mencapai 191.085 .440 orang. Sedangkan proposisi penduduk usia muda (0-14 tahun) turun dari 44,12\% pada tahun 1971 menjadi 23,33\% di tahun 2020. Dari hasil survei tersebut dikombinasikan dengan catatan menurut Kompas.com_Pengguna internet di Indonesia pada awal tahun 2021 mencapai 20,6 juta jiwa. Jumlah ini meningkat 15,5 persen atau 27 juta jiwa jika dibandingkan pada Januari 2020 tahun lalu. Karena tingkat pengguna game di Indonesia sanggat tinggi bahkan menurut ("Jumlah Pecandu Game Online Di Indonesia Diduga Tertinggi Di Asia," 2021). Tercatat total jumlah penduduk Indonesia sendiri saat ini adalah 274,9 juta jiwa. Ini artinya, persentasi internet di Indonesia pada awal tahun 2021 mencapai 73,7 persen ini merupakan angka yang tidak sedikit dan perlu diperhatikan oleh pihak yang berkepentingan. Dari defenisi mengenai metode pembelajaran yang telah dikemukakan dapat disimpulkan dalam kalimat pendek bahwa metode pembelajaran adalah suatu cara yang digunakan oleh guru ataupun siswa dalam kegiatan pembelajaran untuk mencapai tujuan pembelajaran yang diinginkan (Radyuli1 et al., 2019).

Hal inilah yang sebenarnya harus diperhatikan oleh pihak yang berkepentingan, untuk melihat dan menilai dari pengaruh dan dampak yang telah di berikan dari semua aplikasi game yang terdaftar di Play Store yang perlu di saring dan diseleksi sebenarnya, sesuai dengan kebutuhan dan dapak yang diberikan. Dimana dari kebanyakan aplikasi game tersebut tidak memberikan dapat positif hal tersebut, sangat-sangatlah perlu di perhatikan oleh pihak yang berkepentingan terlebih peran dari orang tua dan lingkungan keluarga dikarenakan mempengaruhi tingkat nilai minat seseorang, dalam hal apapun baik dalam hal akademik maupun non akademik yang dipelajari dan yang saat ini sedang di kerjakan. Khusus setiap pembelajaran yang siswa pelajari di sekolah, dimana ketika masa pandemik saat ini yang melanda seluruh dunia sangat sulit melihat keaktifan dari siswa saat pembelajaran daring berlangsung apalagi ketika mempelajari pelajaran matematika dikelas online, yang dimana jika, siswa tersebut sebelum pandemik sudah tidak menyukai pembelajaran matematika karena, kurang menarik dan tidak ada media yang mendukung pembelajaran matematika selain buku pembelajaran, belum lagi ditambah dengan pola pikir yang sudah tertanam dan sulit untuk di hilangkan tetang betapa sulitnya belajar matematika di sekolah. Belum lagi guru yang memebrikan penjelasan secara monoton dan metode yang kurang tepat. Disaat pembelajaran daring saat ini, sangat sulit bagi guru-guru untuk bisa memastikan apakah setiap siswa memperhatikan apa yang di sampikan dan apakah mereka berminat dalam mempelajari suatu pelajaran saat pembelajaran online, dan terkusus yang ingin diketahu saat ini adalah pembelajaran matematika. Untuk itu diperlukan suatu cara yang kreatif dalam meningkatkan nilai minat 
belajar siswa, dari suatu system aplikasi game matematika yang berupa System prodigy math game. Yang dimana siswa akan di ajak untuk menjelajahi berbagai tempat sambil mengerjakan berbagai misi yang berupa soal matematika yang sudah di ataur oleh guru, dan siswa juga dapat terhubung dengan seluruh penguna prodigy math game diseluruh dunia asalkan ada kode kelas yang diberikan. Sehingga semangkin sering siswa tersebut bermain prodigy math game maka semangkin bersar pengaruh dari cara siswa mengidentifikasi dan memecahan masalah dalam kehidupan sehari-hari yang dimana ternyata sebenarnya sangat sering digunakan dalam kehidupan sehari-hari namun, sering tidak disadari siswa tersebut telah menggunakannya secara bersamaan. (Lyons, 2020). Maka hal tersebut jika sering diterapkan dapat meningkatkan semangat belajar matematika, mengingat pembelajaran matematika itu sendiri diharapkan dapat mengajarkan seseorang untuk dapat bisa berpikir logis, kritis, analisis, sistematis, dan kreatif (Sihotang, 2012).

Dari pernyataan kementrian Pendidikan dan Kebudayaan (Kemendikbud) Indonesia menyatakan slogan Merdeka Belajar yang dimana menjadi suatu arah kebijakan dari Menteri Pendidikan dan Kebudayaan (Mendikbud) Indonesia yaitu bapak Nadim Makarim yang dimana beliau terinspirasi dari filosofi Bapak Pendidikan Nasional yakni Ki Hadjar Dewantara (Kemdikbud, 2021)Dengan filosofi, yang di rujuk dari konsep pembelajaran yang dikemukakan oleh Ki Hajar yakni Momong, Among dan Ngemong. Momong yang memiliki arti bahwa Pendidikan itu harus bersifat mengasuh. Mendidik adalah mengasuh anak dalam dunia. Dalam system among ini, pengajaran memiliki arti mendidik anak menjadi manusia yang merdeka batinnya, merdeka pikirannya, dan merdeka tenaganya. Mengemong anak berarti memberi kebebasan anak bergerak menurut keinginannya, tetapi pamong akan bertindak, jika perlu dengan paksaan, apabila keinginan anak-anak berpotensi untuk membahayakan keselamatannya. Pada dasarnya penelitian ini mengkaji secara kritis keterkaitan dari system prodigy math game sebagai implementasi merdeka belajar dalam meningkatkan minat belajar matematika pada saat pembelajaran daring berlangsung, yang dimana sebagai media tambahan untuk belajar matematika pada saat pembelajaran daring dalam kaitannya dengan Merdeka Belajar (Istiq'faroh, 2020). Tidak bisa di lepaskan karena System prodigy math game sangat berpengaruh dari cara mengidentifikasi dan pemecahan masalah dalam kehidupan sehari-hari dalam kaitannya sengan Merdeka Belajar pada System prodigy math game. Dilihat dari hasil analisis besar sekali pengaruh dari System prodigy math game terhadap meningkatkan minat belajar siswa pada saat pembelajaran daring.

\section{METODE PENELITIAN}

Jenis penelitian ini menggunakan kajian studi pustaka yang dimana dengan menggunakan pendekatan analisis system prodigy math game sebagai salah satu media tambahan untuk belajar matematika pada saat pembelajaran daring berlangsung. Sumber yang diambil merupakan sumber primer dan data sekunder, yang di mana meliputi implementasi dari Merdeka Belajar dalam meningkatkan minat belajar matematika Siswa Menegah Atas (SMA) pada pembelajaran daring. Pengumpulan data dilakukan dengan teknik pustaka (library reseach). Data yang telah terkumpul dianalisis secara kualitatif dengan pendekatan induktif yang mengacu pada permasalahan yang ada dalam kehidupan sehari-hari siswa pada saaat pembelajaran daring. Melalui berbagai jurnal nasional dan jurnal internasional tersebut pendekatan analisis system prodigy math game dikaji agar bisa digunakan dalam implementasi sistem merdeka belajar yang di sampaikan oleh Menteri Pendidikan dan Kebudayaan Republik Indonesia yaitu bapak Nadim Makarim. Perlu di pahami bahwa system prodigy math game sebagai salah satu media tambahan belajar mateamtika pada saat pembelajaran daring agar menumbuhkan minat belajar matematika (Fahlevi, n.d.). 
3924 Penerapan Sistem Prodigy Math Game sebagai Implementasi Merdeka Belajar dalam Meningkatkan Minat Belajar Siswa Menengah Atas - Yelsi Enny A, Hotmaulina Sihotang

DOI: https://doi.org/10.31004/edukatif.v3i6.1230

\section{HASIL DAN PEMBAHASAN PENELITIAN}

Prodigy math game merupkan game matematika yang populer untuk kalangan siswa dan guru di negara eropa. Sistem prodigy dapat dimainkan dalam kalangan siswa Sekolah Dasar (SD) hingga Sekolah Menengah Atas (SMA), aplikasi ini sudah banyak digunakan diberbagai negara seperti eropa dan negra yang lainya dari hasil analisis yang dilakukan negara Indonesia sepertinya masih belum terlalu banyak yang menggunakan aplikasi tersebut sebagai media tambahan untuk belajar matematika kuhsusnya pada saat pembelajaran daring. Untuk itu dalam meningkatkan minat belajar siswa peran guru dan lingkungan keluarga di tuntut untuk saling melengkapi dan mendukung. Dikarenakan kurangnya minat belajar siswa pada saat pembelajaran dari untuk itu peran guru yang dimana sanggat di perlukan bukan hanya sekedar professional dalam pembentukan nilainilai karakter di sekolah namun, saat daring pun sanggat-sanggat diperlukan dan di tuntut untuk bisa kreatif mampu membuat kombinasi baru dalam mengatasi kondisi yang sulit untuk bisa memastikan apakah siswa yang di ajarkan dapat menikuti pembelajaran disekolah dengan baik atau tidak dapat mengikuti pembelajaran yang di ajarkan saat daring (Suka Nikmat Zebua1 $\square$ \& Erlina3, 2021).

Perlu diketahui dampak yang diberikan dari penggunaan aplikasi system prodigy math game tersebut sangat siknifikan dikarenakan, system prodigy math game dirancang dalam bentuk game pertualangan dimana anak-anak dapat belajar sambil melatih keterampilan mereka untuk memilih dan memiliki banyak karakter didalam game tersebut. Sehingga mereka dapat memiliki ide-ide yang menarik dalam memecahkan suatu rintangan atau masalah yang sedang dialami. Kemudian, anak-anak diajak untuk menjelajahi banyak tempat dan bertarung dengan monster atau pemain lainnya, yang dimana bisa terhubung asalkan memiliki kode pasword dari kelas yang sama. Dalam perjalanan tersebut anak-anak tersebut haurs menyelesaikan soal matematika yang sudah diataur oleh guru untuk bisa naik level dan menyelesaikan pertualangan dengan baik. Jadi prodigy math game ini bisa dijadikan media tambahan untuk belajar matematika, dan tidak meninggalkan nilai asli dalam pembelajaran matematika yaitu siswa di tuntut untuk dapat memahami konsep, sedangkan konsep-konsep dasar matematika merupakan kesatuan holistic dan komprehensif menggunakan komunikasi digital (Sefriani1 \& Sepriana2, 2020). Sehingga dari keterkaitan tersebut membentuk kebebasan bagi siswa dan memberikan mereka ruang, sehingga siswa tersebut dapat berminat dalam belajar secara daring dan terlibat secara aktif dalam pembelajaran yang berlangsung disaat daring. Karena, keingintahuan mereka yang besar dan kebebasan yang diberikan untuk dapat melatih berpikir kritis siswa untuk itu penerapan dari Convergent Thinking dan Convergent Thinking dapat terlaksana dengan baik dan berjalan dengan seimbang.

Dengan kelebihan fasilitas yang dimiliki Prodigy math game. Pengguna yang mengunakannya dapat mengakses secara free atau bisa dikatakan tidak sama sekali di pungut biaya jika mendaftar dan menggunakan aplikasi ini, kemudaian tampilan yang engaging menambah daya tarik siswa belum lagi pertanyaanpertanyaan yang diberikan dapat diatur sesuai kebutuhan siswa, ini salah satu kelebihan yang dimiliki aplikasi Prodigy math game didalam aplikasi tersebut disediakannya berbagai banyak pilihan kurikulum, yang dimana mencangkup dari hampir seluruh materi pembelajaran matematika dari Selolah Dasar (SD) hingga Sekolah Menegah Atas (SMA) di Indonesia. Selain itu guru juga dapat menyediakan pertanyaan tertentu kepada beberapa siswa saja. Jika,ditemui ada siswa yang tidak dapat mengikuti setiap soal yang diberikan sesuai kelas dan materi yang disampaikan didalam pembelajaran daring berlangsung. Selanjutnya terdapat laporan yang rinci dari aplikasi psikologi terkait progress siswa yang sudah tersistem didalam apliasi tersebut. Jadi, dari setiap pertanyaan yang di jawab siswa akan di data dan di analisis oleh prodigy math game secara tersistem otomatis. Apakah siswa tersebut kesulitan dalam menjawab soal-soal tertentu, atau siswa tersebut sudah bisa dikatakan mampu dan bisa menyelesikan permasalahan yang ada didalam soal. Dikarenakan siswa telah berhasil menjawab pertanyaan-pertanyaan yang di berikan maka, siswa tersebut dapat melanjutkan misi berikutnya dan bisa terhubung dengan teman-teman yang laiannya jika, memiliki kode kelas yang sama.

Selanjutnya ada perencanaan belajar yang dapat di pilih untuk menentukan topik apa saja yang akan digunakan pada prodigy math game dalam waktu tertentu menggunakan komunikasi digital (. Sehingga dapat 
di kontrol dengan sangat mudah dan tentunya sudah tersistem secara otomatis. Selanjutnya ada Ujian Akhir yang dapat di kerjakan melalui aplikasi tersebut, dan bukan hanya itu saja anak-anak diberikan pertanyaan yang disuguhkan dalam bentuk manipulative. Jadi, tidak serta merta pertanyaan matematika itu seperti $1+1=2$ atau $2+2=4$ tapi, ada manipulatif atau bentuk real yang bisa anak-anak lihat dalam menjawab pertanyaan matematika yang anak-anak akan jawab nantinya. Sehingga konsep "Merdeka Belajar" menurut filsafat Ki Hadjar Dewantara dan yang sudah di canangkan oleh Menteri Pendidikan dan Kebudayaan (Mendikbud) Indonesia yaitu bapak Nadim Makarim yang dimana menekankan adanya kemerdekaan dan kebebasan dalam memaksimalkan kemampuan belajar seseorang yang dimiliki oleh guru dan peserta didik sehingga konsep merdeka belajar yang di canagkan dapat terlaksana dengan baik (Ainia, 2020). Karena perserta didik harus bebas berkarya serta berkembang secara natural demi mengupayakan minat belajar seseorang secara kuhsus pembelajaran matematika dikarenakan banyak didapati bahwa pelajar Indonesia tidak menyukai pembelajaran matematika, dari siswa yang sudah tertanam dari kecil bahwa matematika itu sulit dan tidak menyenangkan dan belum lagi media yang digunakan saat belajar tidak menarik karena pembelajaran yang di berikan bersifat menoton, hal tersebutlah yang kerapkali membuat siswa tidak menyukai pembelajaran matematika. Agar disaat pembelajaran darling siswa dapat tertarik dan pada akhirnya dapat berpikir logis, serta kritis, analisis, sistematis, dan kreatif pada saat daring. Untuk itu diperlukan media yang tepat seperti Prodigy math game.

Mengingat konsep filsafat dari Ki Hadjar Dewantara yang menunjukan bahwa Pendidikan yang baik adalah pendidikan humanis yakni memanusiakan manusia (Noviani, 2017). Karena itu, perlu perubahan yang dinamis dan sesuai dengan perkembangan jaman dan kondisi yang menuntut segala aspek kehidupan untuk berpikir maju dan dapat menyesuaikan perkembanagan jaman. Kemudian konsep inilah yang mendasari Nadim dalam merumuskan kebijakan Merdeka Belajar. Pendidikan dapat dinilai baik karena bersifat terbuka dan tidak memaksa dari berbagai pihak dari guru serta perserta didik untuk dapat menyampaikan ide dan gagasan, demi mewujudkan terlaksananya merdeka belajar yang di cangakan oleh bapak Nadim. Dengan demikian dapat dikatakan bahwa hasil penelitian keputusan ini menunjukkan bahwa adanya relevansi yang sangat mendasar dalam implementasi dari kebijakan "Merdeka Belajar" dengan filsafat yang dikemukakan oleh tokoh besar masyarakat Indonesia yaitu Ki Hadjar Dewantara dengan penggunaan system prodigy math game sebagai implementasi merdeka belajar dalam meningkatkan minat belajar matematika pada saat pembelajaran daring berlangsung (Baro'ah, 2020). Pada dasarnya penelitian ini mengkaji secara kritis keterkaitan dari system prodigy math game sebagai implementasi merdeka belajar dalam meningkatkan minat belajar matematika yang dimana sebagai media tambahan untuk belajar matematika pada saat pembelajaran daring (Istiq'faroh, 2020).

\section{KESIMPULAN}

Dari berbagai uraian di atas dapat disimpulkan bahwa, Proses penggunaan suatu system media pembelajaran dari suatu media pembelajaran yang berupa aplikasi prodigy mate game, sangat berpengaruh dalam meningkatkan semangat belajar matematika, mengingat pembelajaran matematika itu sendiri diharapkan dapat mengajarkan seseorang untuk dapat bisa berpikir logis, kritis, analisis, sistematis, dan dapat dikatakan bahwa hasil penelitian keputusan ini menunjukkan bahwa adanya relevansi yang sangat mendasar dalam implementasi dari kebijakan "Merdeka Belajar" dengan filsafat yang dikemukakan oleh tokoh besar masyarakat Indonesia yaitu Ki Hadjar Dewantara dengan penggunaan system prodigy math game sebagai implementasi merdeka belajar dalam meningkatkan minat belajar matematika pada saat pembelajaran daring berlangsung. Dari jiwa merdeka yang dikemukakan oleh Ki Hadjar Dewantara yang dimana berisi tujuan pendidikan yang pada hakikatnya ialah memerdekakan hidup, dan menumbuhkan kepercayaan diri dari masing-masing individu akan dapat tercapai jika, memiliki kesatuan yang saling mendukung dan melengkapi satu sama lain hingga terwujudnya jiwa merdeka tersebut. Untuk itu pada pembelajaran daring diperlukanlah 
suatu media pembelajaran yang dimana dapat memicu serta mendong siswa untuk berminat dalam belajar yaitu dengan penggunaan system momong, among, dan nemong. Pada sistem among yang dimana mengandung makna bahwa pengajaran berarti mendidik seorang anak untuk dapat menjadi seoarang manusia yang harus merdeka hatinya, merdeka pikirannya, merdeka tenaganya. Oleh karena itu penerapan dari penggunaan System among inilah yang menjadi landasan terbentuknya kebijakan "Merdeka Belajar" dalam memajuan kesajahteraan pendidikan bangsa Indonesia ditengah-tengah kondisi pandemik Covid 19 yang sulit (Susilo, 2018). Dari antara konsep "Merdeka Belajar" yang dicetuskan oleh Mendikbud yaitu bapak Nadiem Anwar Makarim ternyata memiliki kesamaan dengan konsep Pendidikan menuerut Ki Hajar Dewantara, yakni keduanya sama-sama menekankan adanya kemerdekaan belajar mengingat kesamaan tersebut untuk itu diterapkanlah konsep merdeka belajar yang dimana menekankan kemerdekaan belajar bagi setiap orang, maka dengan menerapkan serta menekankan hal tersebut diharapkan dapat mewujudkan cita-cita bangsa Indonesia serta menumbuhkan nilai minat belajar dari diri masing-masing siswa, melalui dukungan dari orang-orang disekitar dan guru yang mewadahi serta mefasilitasi apa yang menjadi kebutuhan dari siswa itu sendiri dengan melihat peluang yang akan terjadi dimasa mendatang (Mardiana1 \& Umiarso2, 2020).

\section{DAFTAR PUSTAKA}

Aiman Faiz1, I. K. (2020). Konsep Merdeka Belajar Pendidikan Indonesia Dalam Perspektif Filsafat Progresivisme. Urnal Pendidikan Dan Pembelajaran, 12(2).

Ainia, D. K. (2020). Merdeka Belajar Dalam Pandangan Ki Hadjar Dewantara Dan Relevansinya Bagi Pengembanagan Pendidikan Karakter. Jurnal Ilmu Pendidikan, 3(3).

Baro'ah, S. (2020). Kebijakan Merdeka Belajar Sebagai Strategi Peningkatan Mutu Pendidikan. Issn Journal, $4(1)$.

Fahlevi, K. (N.D.). Peneparan Media Pembelajaran Aplikasi Permainan Matematika Pada Playstore Dalam Meningkatkan Pemahaman Siswa. Jurnal Pendidikan.

Hotmaulina Sihotang1*), Bernadetha Nadeak2), Dan R. S. (2020). Penerapan Belajar Mandiri Dengan Strategi Efektif Pada Masa Pandemi Covid 19 Bagi Remaja Hkbp Duren Jaya Bekasi. Jurnal Comunita Servizio, 2(2).

Istiq'faroh, N. (2020). Relevansi Filosofi Ki Hajar Dewantara Sebagai Dasar Kebijakan Pendidikan Nasional Merdeka Belajar Di Indonesia. Jurnal Pendidikan, 3(2).

Jumlah Pecandu Game Online Di Indonesia Diduga Tertinggi Di Asia. (2021). Liputanmedia.

Kemdikbud, Pengelola Web. (2021). Nadiem Anwar Makarim Emban Amanah Baru Sebagai Menteri Pendidikan, Kebudayaan, Riset, Dan Teknologi. Kementrian Pendidikan Dan Kebudayaan.

Krisbiantoro1, D., \& Haryono2, D. (2017). Game Matematika Sebagai Upaya Peningkatan Pemahaman Matematika Siswa Sekolah Dasar. Jurnal Telematika, 10(2).

Lyons, C. (2020). Identifying Opportunities And Challenges Of Using Prodigy Math In A Sixth Grade Math Classroom. Education.

Mardiana1, D., \& Umiarso2. (2020). Merdeka Belajar Di Tengah Pandemi Covid-19: Studi Di Sekolah Menengah Pertama Di Indonesia. Jurnal Kajian Ilmu Pendidikan, 13(2).

Mustaghfiroh, S. (2020). Konsep "Merdeka Belajar"Perspektif Aliran Progresivisme John Dewey. Jurnal Studi Guru Dan Pembelajaran, 3(1).

Noviani, Y. Dkk. (2017). Pendidikan Humanistik Ki Hadjar Dewantara Dalam Konteks Pendidikan Kontemporer Di Indonesia. Jurnal Pendidikan.

Radyuli1, P., Sefriani2, R., \& Qomariah3, N. (2019). Pembelajaran Inquiry Menggunakan Google Form 
3927 Penerapan Sistem Prodigy Math Game sebagai Implementasi Merdeka Belajar dalam Meningkatkan Minat Belajar Siswa Menengah Atas - Yelsi Enny A, Hotmaulina Sihotang

DOI: https://doi.org/10.31004/edukatif.v3i6.1230

Terhadap Hasil Belajar Simulasi Dan Komunikasi Digital. Jurnal Ilmu Pendidikan, 1(2).

Samho, B. (2014). Pendidikan Karakter Dalam Kultur Globalisasi: Inspirasi Dari Ki Hadjar Dewantara. Jurnal Ilmu Pendidikan, 20(3).

Sefriani1, R., \& Sepriana2, R. (2020). Pengembangan Media E-Learning Berbasis Schoology Pada Pembelajaran Kurikulum Pendidikan Teknologi Dan Kejuruan. Jurnal Ilmu Pendidikan, 2(1).

Sihotang, H. (2012). Pengaruh Konsep Diri Dan Berpikir Kritis Terhadap Prestasi Belajar Matematika Siswa Smp Se-Jakarta Timur. Jurnal Dinamika Pendidikan, 5(3).

Sihotang, H. (N.D.). Peran Guru Yang Profesional Dalam Pembentukan Nilai-Nilai Karakter Di Sekolah. Jurnal Ilmu Pendidikan.

Suka Nikmat Zebua1 $\square$, E. S., \& Erlina3. (2021). Pengaruh Kecerdasan Emosional, Kreativitas, Dan Kemampuan Menyesuaikan Diri Terhadap Kinerja Guru Sma. Jurnal Ilmu Pendidikan, 3(6).

Susilo, S. V. (2018). Refleksi Nilai-Nilai Pendidikan Ki Hadjar Dewantara Dalam Upaya Upaya Mengembalikan Jati Diri Pendidikan Indonesia. Jurnal Ilmu Pendidikan, 4(1). 